\title{
Quantitative Physiological Characterization of a Quinoxalinedione non-NMDA Receptor Antagonist
}

\author{
Kelvin A. Yamada, Janet M. Dubinsky, and Steven M. Rothman \\ Departments of Anatomy and Neurobiology and of Pediatrics, Washington University School of Medicine, St. Louis, \\ Missouri 63110
}

The effects of 6-cyano-7-nitroquinoxaline-2,3-dione (CNQX, or FG 9065) on excitatory amino acid responses in cultured neurons from rat hippocampus were studied using tight-seal whole-cell recording techniques. CNQX reduced the magnitude of peak inward currents produced by exogenously applied kainate, quisqualate, and $\mathbf{N}$-methyl-D-aspartate (NMDA) with $K$ 's of 2.5, 3.5, and $96 \mu \mathrm{M}$, respectively. The antagonism was competitive against kainate and quisqualate, but noncompetitive against NMDA. Glycine markedly reduced CNQX antagonism of NMDA responses. The same recording technique using pairs of monosynaptically connected neurons demonstrated reversible diminution of excitatory postsynaptic potentials in 7 of 7 pairs, using $\mathrm{CNQX}$ at concentrations as low as $10 \mu \mathrm{M}$. CNQX applied alone did not evoke inward or outward currents at membrane potentials near the resting membrane potential and did not affect the current-voltage relationship at membrane potentials between -90 and $-30 \mathrm{mV}$. These observations represent the first quantitative characterization of glutamate receptor antagonism by CNQX with respect to physiological rather than biochemical parameters and demonstrate that CNQX is far more potent and more selective than currently available nonNMDA antagonists. The results suggest that CNQX will be a useful pharmacologic tool for the study of synaptic transmission in a variety of systems in which glutamate or related excitatory amino acids are involved.

Abundant evidence suggests that L-glutamate is an endogenous excitatory neurotransmitter acting at a variety of receptors in the vertebrate CNS (Mayer and Westbrook, 1987). Four receptor subclasses have been identified based upon the selectivity of the agonists $N$-methyl-D-aspartic acid (NMDA), kainic acid (KA), quisqualic acid (QA), and 2-amino-4-phosphonobutyric acid (AP-4) (Cotman and Iverson, 1987).

In many preparations, $\mathrm{KA}$ and/or $\mathrm{QA}$ receptors appear to be responsible for fast excitatory synaptic transmission (Collingridge et al., 1983; Rothman and Samaie, 1985; Nelson et al., 1986). However, examination of the role of KA and QA recep-

\footnotetext{
Received Nov. 11, 1988; revised Feb. 3, 1989; accepted Feb. 13, 1989.

We wish to thank Katherine Holland for help with data analysis, Nancy Lancaster for culture preparation, and Deborah Howard and Jeff Blake for typing the manuscript. We are extremely grateful to Tage Honoré of Ferrosan, who provided the CNQX. This work was supported in part by grants NS19988 and NS07027 from the NIH and by the Monsanto Corporation.

Correspondence should be addressed to Steven M. Rothman, M.D., Department of Anatomy and Neurobiology, Washington University School of Medicine, 660 South Euclid, St. Louis, MO 63110.

Copyright (C) 1989 Society for Neuroscience $0270-6474 / 89 / 093230-07 \$ 02.00 / 0$
}

tors in physiological events has been hampered by the lack of potent, selective antagonists for these receptors. The blockers now used to antagonize KA and QA, usually $\gamma$-D-glutamylglycine (Francis et al., 1980) or kynurenic acid (Robinson et al., 1984) are relatively weak and are actually more potent against NMDA responses. It is likely that many events triggered by activation of $\mathrm{KA}$ or $\mathrm{QA}$ receptors in some preparations are not significantly reduced by these antagonists because of their low potency.

Honoré and colleagues (Drejer and Honoré, 1988; Honoré et al., 1988) have recently described 2 quinoxalinediones, which potently block many $\mathrm{KA}$ and $\mathrm{QA}$ responses. These compounds, 6,7-dinitroquinoxaline-2,3-dione (DNQX, or FG 9041) and 6-cyano-7-nitroquinoxaline-2,3-dione (CNQX, or FG 9065) have largely been tested in binding or other neurochemical paradigms. These types of experiments do not necessarily give direct information about mechanism(s) of action at physiologically relevant sites. The experiments described below provide quantitative, physiological information about $\mathrm{KA}, \mathrm{QA}$, and NMDA blockade by CNQX. They also demonstrate blockade of synaptic potentials by CNQX at concentrations far less than those of other available antagonists.

\section{Materials and Methods}

Cell culture. Neonatal rat hippocampal cell cultures were prepared using methods similar to those previously established for cortical neurons (Huettner and Baughman, 1986). Briefly, hippocampi were removed from postnatal day 1 Sprague-Dawley rats, minced, and incubated for $20 \mathrm{~min}$ in $3 \mathrm{ml}$ Lcibovitz's L-15 cquilibratcd with $95 \% \mathrm{O}_{2} / 5 \% \mathrm{CO}_{2}$ containing $1 \mathrm{mg} / \mathrm{ml}$ papain and $0.2 \mathrm{mg} / \mathrm{ml} \mathrm{BSA}$. The cells were triturated with fire-polished pasteur pipettes in growth medium and centrifuged through $2 \mathrm{ml}$ growth medium containing $10 \mathrm{mg} / \mathrm{ml}$ albumin and 10 $\mathrm{mg} / \mathrm{ml}$ trypsin inhibitor. The cells were resuspended in growth medium and plated onto established cortical glial cultures, $2.5 \times 10^{5}$ cells per $35 \mathrm{~mm}$ petri dish. Approximate yield was $2-3 \times 10^{6}$ cells per rat pup.

Glial cells were harvested from the cortices of 2- to 6-d-old rat pups (McCarthy and de Vellis, 1980) and placed in T-25 flasks. Passaged glial cells were plated onto poly-L-lysine-coated petri dishes $4 \mathrm{~d}$ prior to neuronal plating. One day after plating neurons, cultures were treated with 5-fluoro-2-deoxyuridine $(15 \mu \mathrm{g} / \mathrm{ml})$ and uridine $(35 \mu \mathrm{g} / \mathrm{ml})$. Growth medium for all cultures was Eagle's MEM lacking glutamine and supplemented with $10 \%$ Nuserum (Collaborative Research). Penicillin ( 20 units $/ \mathrm{ml})$ and streptomycin $(20 \mu \mathrm{g} / \mathrm{ml})$ were added to inhibit bacterial growth.

Electrophysiology. Experiments were performed on the stage of an inverted microscope at room temperature. Cell cultures were used $1-4$ weeks after plating. Growth medium was replaced by an extracellular recording solution containing (in $\mathrm{mm}$ ) $140 \mathrm{NaCl} ; 3 \mathrm{KCl} ; 4 \mathrm{CaCl}_{2} ; 4$ $\mathrm{MgCl}_{2} ; 10$ HEPES; and 5.5 glucose, $\mathrm{pH}$ 7.3. All NMDA responses were obtained using a recording solution containing $5 \mu \mathrm{M}$ or $1 \mathrm{~mm}$ glycine, $5 \mathrm{mM} \mathrm{CaCl}_{2}$, and no added magnesium. Tetrodotoxin $(1 \mu \mathrm{g} / \mathrm{ml})$ was added to all recording solutions in voltage-clamp experiments to block regenerative sodium conductances. All drugs and reagents were obtained 
A

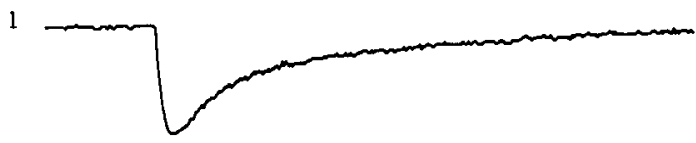

2

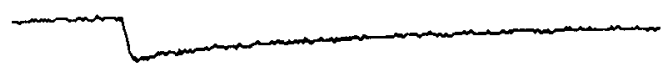

3
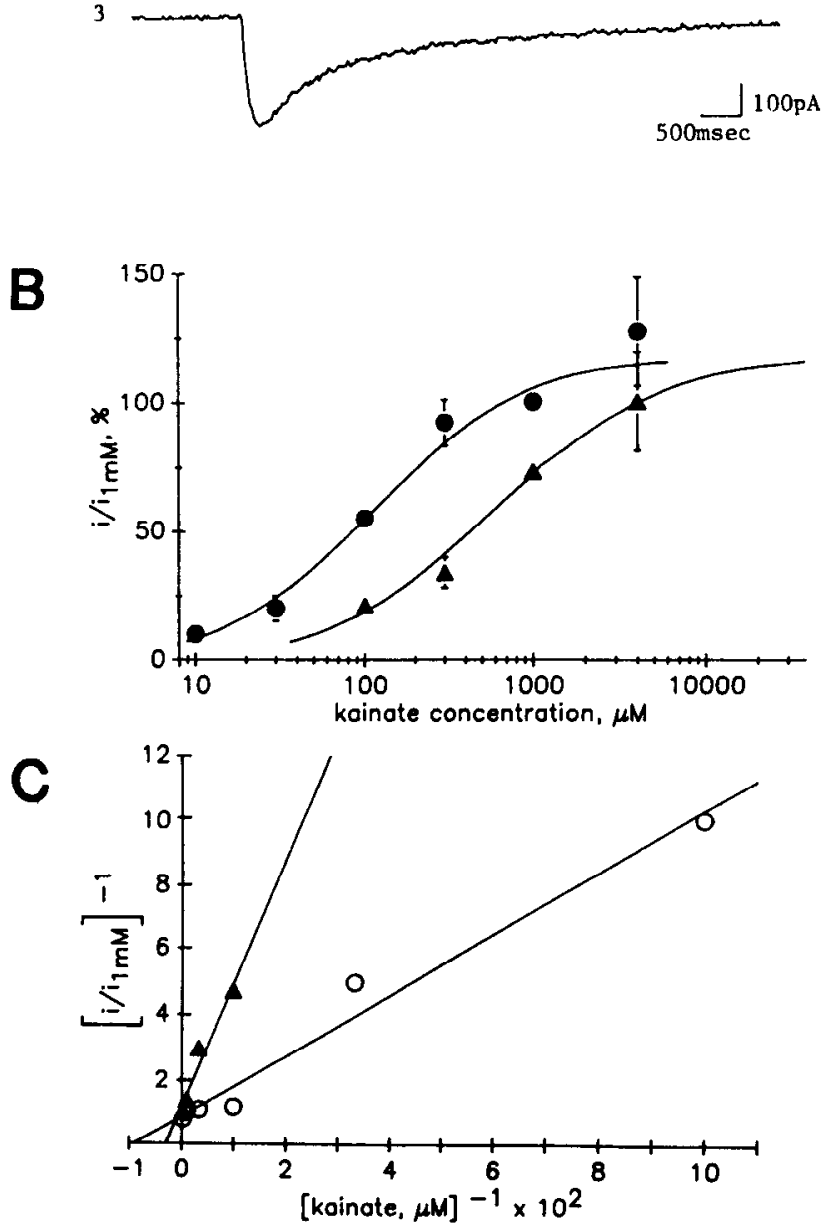

Figure 1. Effect of CNQX against KA responses. $A$, Current traces from a neuron in response to $100 \mu \mathrm{M} \mathrm{KA}$ alone $(I)$ and with $5 \mu \mathrm{M} \mathrm{CNQX}$

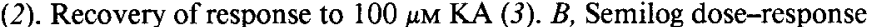
curves for KA (circles) and KA after $5 \mu \mathrm{M}$ CNQX (triangles). Error bars are SEM. Each point represents 4-7 cells. $C$, Double-reciprocal plots of data from $B$, excluding the point at $10 \mu \mathrm{M}$. For KA alone (circles): $\left(i / i_{1}\right)^{-1}=94.1 \times[\mathrm{KA}, \mu \mathrm{M}]^{-1}+0.862 ; r=0.99 . K_{d}=$ slope $/ y$-intercept $=110 \mu \mathrm{M}$. For $\mathrm{KA}$ with $5 \mu \mathrm{M}$ CNQX (triangles): $\left(i / i_{1 \mathrm{mM}}\right)^{-\mathrm{i}}=378 \times$ $[\mathrm{KA}, \mu \mathrm{M}]^{-1}+1.15 ; r=0.99$. Apparent $K_{d}=\left(1+I / K_{i}\right) \times K_{d}$; therefore, $K_{i}=2.5 \mu \mathrm{M}$. See Materials and Methods, equations 4-7. In Figures 13 lines are derived from a least-squares fit of the data.

from Sigma (St. Louis, MO), except CNQX, which was a gift of Tage Honoré, and $\gamma$-amino-methyl sulfonic acid (GAMS), which was purchased from Tocris Neuramim (London, England).

Intracellular recording utilized the whole-cell patch-clamp configuration (Hamill et al., 1981). Electrodes (4-7 M $\mathrm{DC}$ resistance) were filled with an intracellular recording solution containing (in $\mathrm{mM}$ ) 130 potassium acetate, $10 \mathrm{KCl}, 10 \mathrm{HEPES}, 1.1 \mathrm{EGTA}$, and $2 \mathrm{Mg}$-ATP. They were connected to an Axoclamp 2A amplifier (Axon Instruments) used in either the continuous single-electrode voltage-clamp mode with series resistance compensation or bridge mode (for the synaptic pair experiments). Data were collected on a chart recorder or digitized at 6 or 30
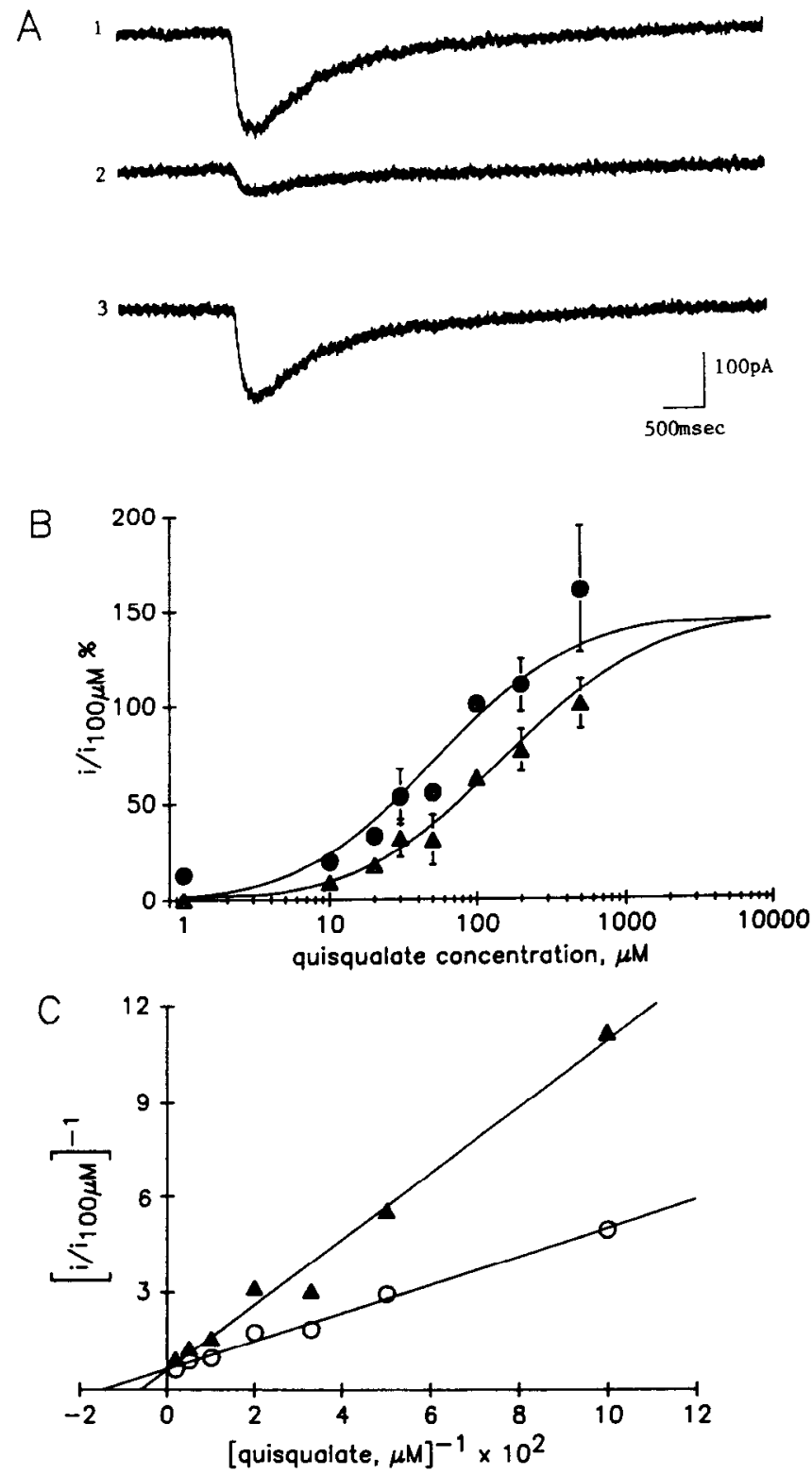

Figure 2. Effect of C.NQX against $Q A$ responses. $A$, Current trace from a neuron in response to $50 \mu \mathrm{M}$ QA alone (1) and with $5 \mu \mathrm{M}$ CNQX (2). Recovery of response to $50 \mu \mathrm{M}$ QA (3). B, Semilog dose-response curves for Q $\Lambda$ (circles) and QA after $5 \mu \mathrm{M}$ CNQX (triangles). Each point represents 3-16 cells. $C$, Double-reciprocal plots of data from $B$, excluding the point at $1 \mu \mathrm{M}$. For QA alone (circles): $\left(i / i_{100}\right)^{-1}=44 \times[\mathrm{QA}, \mu \mathrm{M}]^{-1}$ $+0.654 ; r=0.99 . K_{d}=67 \mu \mathrm{M}$. For QA with $5 \mu \mathrm{M}$ CNQX (triangles): $\left(i / i_{100 \mu \mathrm{M}}\right)=102 \times[\mathrm{QA}, \mu \mathrm{M}]^{-1}+0.624 ; r=0.99 . K_{i}=3.5 \mu \mathrm{M}$. See Materials and Methods, equations 4-7.

$\mathrm{kHz}$ (Modular Instruments M- 100 interface) and stored on disk for later analysis.

For drug application, pipettes identical to those used for patch electrodes were filled with agonists or antagonists dissolved in cxtraccllular recording solution. Brief pulses of air pressure $\left(2-7 \times 10^{4} \mathrm{~Pa}\right)$ ejected drugs (Choi and Fischbach, 1981). At high concentrations of agonist, leakage required use of smaller tipped pipettes (10-12 M $\Omega$ DC resistance).

For dose-response experiments, cells were voltage-clamped at resting membrane potential and drug pipettes were placed $<50 \mu \mathrm{m}$ from the cell body. Agonist was applied for $100 \mathrm{msec}$, both before and immediately after a $2 \mathrm{sec}$ application of CNQX. Averages of 2 or more peak current responses from each concentration of agonist, with and without antagonist, were normalized to responses produced by application of a 


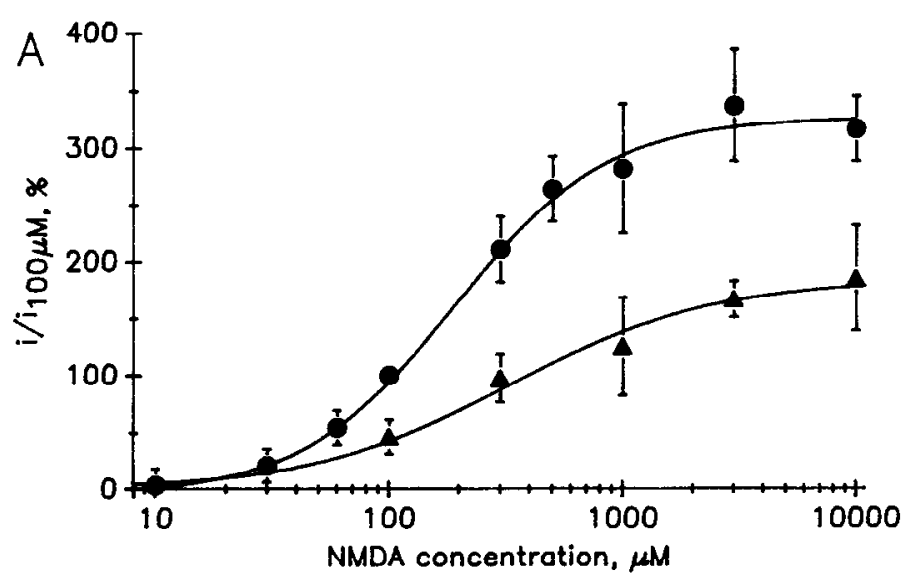

C
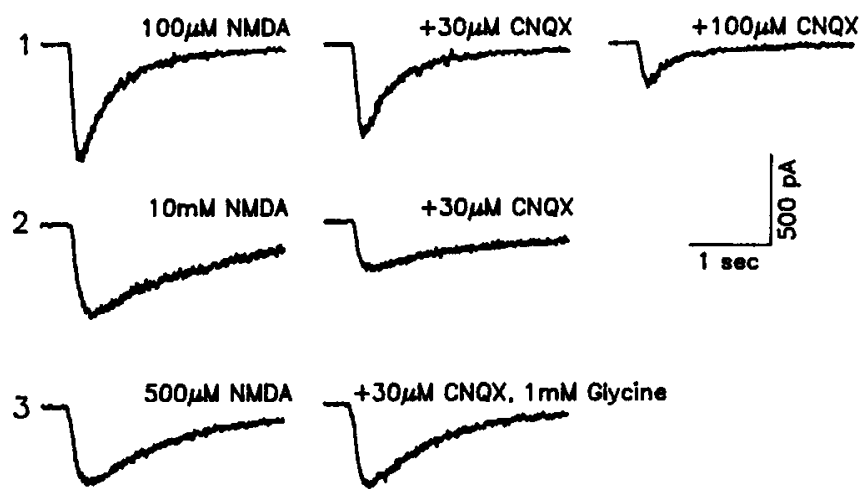
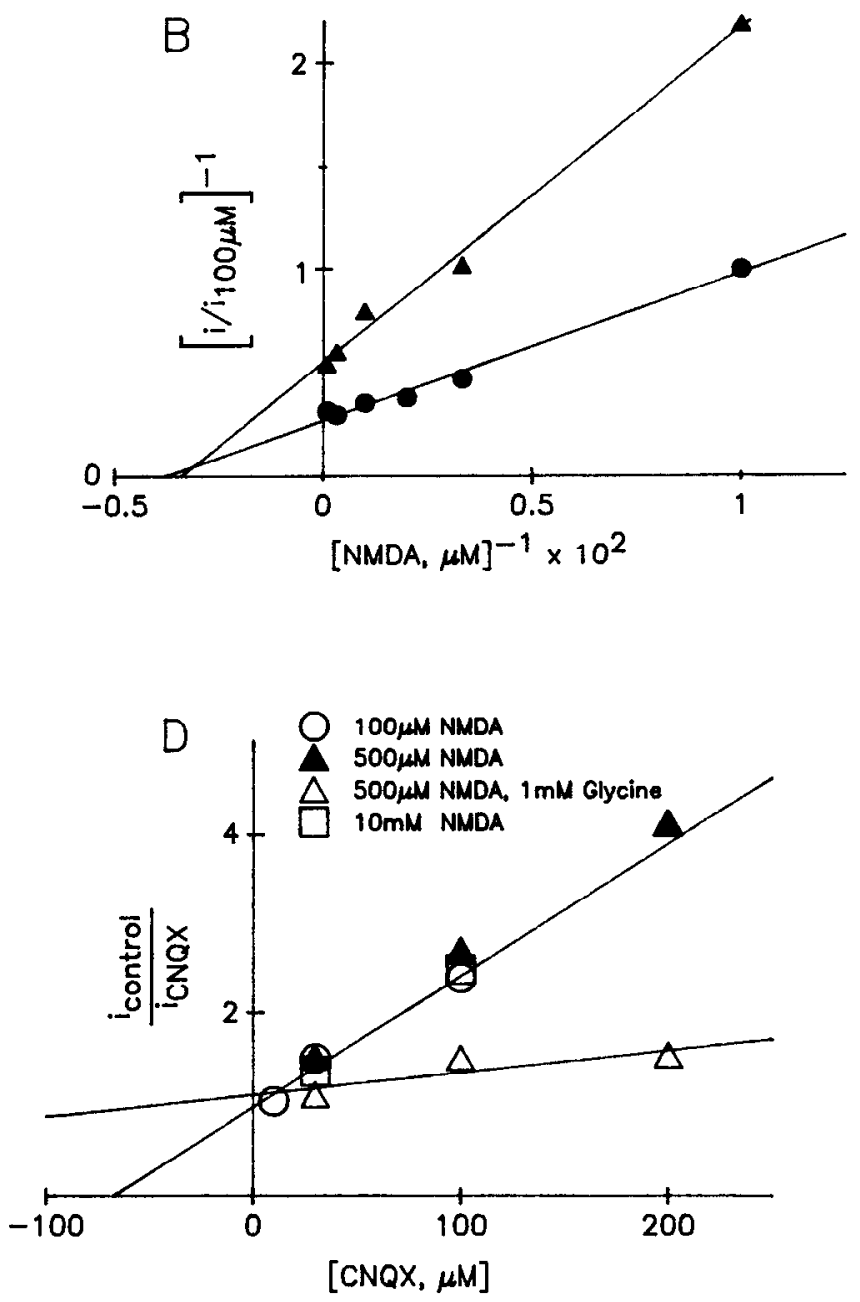

Figure 3. Effect of CNQX against NMDA responses in conditions of low magnesium and $5 \mu \mathrm{M}$ glycine. $A$, Semilog dose-response curve for NMDA (circles) and after $100 \mu \mathrm{M}$ CNQX (triangles). High concentrations of NMDA cannot overcome CNQX antagonism. Each point represents 3-12 cells. $B$, Double-reciprocal plot of data from $A$, excluding points at 10,30 , and $60 \mu \mathrm{M}$. For NMDA alone $($ circles $):\left(i / i_{100}\right)^{-1}=71.3 \times$ $[\mathrm{NMDA}, \mu \mathrm{M}]^{-1}+0.27 ; r=0.99$. For NMDA with $100 \mu \mathrm{M}$ CNQX (triangles): $\left(i / i_{100 \mu \mathrm{M}}\right)^{-1}=161.6 \times[\mathrm{NMDA}, \mu \mathrm{M}]^{-1}+0.55 ; r=0.99 . K_{d}=260$ $\mu \mathrm{M}, K_{i}=96 \mu \mathrm{M}$. See Materials and Methods, equations 8, 9. C, Current traces from 3 neurons in response to NMDA. 1 , Responses to $100 \mu \mathrm{M}$ NMDA alone and with 30 and $100 \mu \mathrm{M}$ CNQX. 2, Responses to $10 \mathrm{~mm}$ NMDA alone and with $30 \mu \mathrm{M}$ CNQX. CNQX antagonism could not he overcome by high concentrations of NMDA. 3, Responses to $500 \mu \mathrm{M}$ NMDA alone and with $30 \mu \mathrm{M}$ CNQX in the presence of $1 \mathrm{mM}$ glycine in the extracellular solution. CNQX antagonism is significantly reduced. $D$, Plot of $i / i_{C N Q X}$ vs CNQX concentration demonstrating reduction of NMDA responses independent of NMD $\Lambda$ concentration. Slope of the top line gives a $K_{i}-71 \mu \mathrm{M}$ (see Materials and Methods, equation 9); the bottom line gives an apparent $K_{i}=410 \mu \mathrm{M}$; experimental conditions were the same except for $1 \mathrm{~mm}$ glycine in the extracellular solution.

\begin{tabular}{|c|c|c|c|c|}
\hline Glutamate & Kainate & $\begin{array}{l}\text { Quis- } \\
\text { qualate }\end{array}$ & NMDA & Method \\
\hline 30 & 200 & - & - & $\begin{array}{l}\text { Cultured chick spinal } \\
\text { neurons (Vlachova } \\
\text { et al., 1987) }\end{array}$ \\
\hline 1100 & 500 & 93 & - & $\begin{array}{l}\text { Rat hippocampal } \\
\text { neurons (Kiskin et } \\
\text { al., 1986) }\end{array}$ \\
\hline 660 & 110 & 67 & 260 & $\begin{array}{l}\text { Cultured rat } \\
\text { hippocampal } \\
\text { neurons (present } \\
\text { study) }\end{array}$ \\
\hline
\end{tabular}

The $K_{d}$ of $660 \mu \mathrm{M}$ glutamate is included for comparison; it was obtained using the same methods as described in Materials and Methods. control concentration $\left(i_{\text {control }}\right)$ of the same agonist ( $1 \mathrm{mM}$ for kainate; 100 $\mu_{\mathrm{M}}$ for NMDA and quisqualate). Therefore, each cell was its own control for the variability of absolute values of peak currents as a function of cell size. Average responses were collected from 3-18 cells at a given concentration to establish one data point on the dose-response curve.

Data analysis. We assume that the receptor-channel interaction can be represented in chemical terms, obeying laws of mass action. In addition, we assume that the agonist (or inhibitor)-receptor interaction equilibrates rapidly and that the observed physiological response resulting from agonist-receptor binding is proportional to receptor occupancy:

$$
\begin{aligned}
& A \text { (agonist) }+R \text { (receptor-channel) } \underset{k_{-1}}{\stackrel{k_{+1}}{\rightleftharpoons}} A R, A R \alpha \text { response }=i \text { (inward } \\
& \text { current) }
\end{aligned}
$$

At equilibrium, the forward and reverse fluxes are equal such that

$$
k_{+1}[A][R]=k_{-1}[A R] \text {. }
$$

If $p$ is the fraction of receptors occupied to give $A R,(1-p)=R$ and rearrangement of equation 1 gives 


$$
p=\frac{K_{a} \times[A]}{\left(1+K_{a} \times[A]\right)}, \text { where } K_{a}=\frac{k_{+1}}{k_{-1}}=\frac{1}{K_{d}}
$$

Since $p$ is proportional to the observed response (i.e., $i / i_{\text {control }}$ ), a proportionality constant yields

$$
\frac{i}{i_{\text {control }}}=C \times \frac{K_{a} \times[A]}{\left(1+K_{a} \times[A]\right)}
$$

Taking the reciprocal of both sides gives the following linear relationship (Segel, 1976; Barlow, 1980):

$$
\frac{i_{\text {control }}}{i}=K_{d} \times C^{\prime} \times \frac{1}{[A]}+C^{\prime}
$$

If $i_{\text {control }} / i$ is plotted against $1 /[A]$,

$$
K_{d}=\text { slope } / y \text {-intercept }
$$

In the presence of a competitive antagonist, $[I]$,

$$
\begin{gathered}
\frac{i_{\text {control }}}{i_{\text {inhibited }}}=K_{d} \times C^{\prime} \times\left(1+\frac{[I]}{K_{i}}\right) \times \frac{1}{[A]}+C^{\prime} \\
\text { “apparent } K_{d}^{\prime \prime}=\left(1+\frac{[I]}{K_{i}}\right) \times K_{d,} \text { where }[I]=[\text { CNQX] }
\end{gathered}
$$

If $I$ is a noncompetitive antagonist,

$$
\frac{i_{\text {control }}}{i}=K_{d} \times\left(1+\frac{[I]}{K_{i}}\right) \times C^{\prime} \times \frac{1}{[A]}+\left(1+\frac{[I]}{K_{i}}\right) \times C^{\prime}
$$

and

$$
\frac{i}{i_{\text {inhibited }}}=\frac{1}{K_{i}} \times[\mathrm{I}]+1
$$

These equations enable calculation of the $K_{i}$ by plotting $i_{\text {control }} / i$ versus $1 /[A]$ in the presence of fixed $[I]$ or by varying $[I]$ in the presence of fixed $[A]$. The semilog dose-response curves were fit by probit analysis (Finney, 1971).

Synaptic responses. In order to test the effect of CNQX on excitatory postsynaptic potentials (EPSPs), current-clamp recordings from 2 synaptically connected neurons were obtained with 2 whole-cell electrodes. Bicuculline, $100 \mu \mathrm{M}$, was added to the extracellular solution to eliminate inhibitory postsynaptic potentials. Consistent EPSPs with onset $\leq 5 \mathrm{msec}$ after the peak of the presynaptic action potential were considered monosynaptic. Action potentials were triggered every $10 \mathrm{sec}$ by depolarizing current injection and only pairs of cells in which $>90 \%$ of action potentials resulted in an EPSP were used in the analysis. CNQX, 10 and $100 \mu \mathrm{M}$, was applied near the postsynaptic neuron during a continuous train of evoked EPSPs.

\section{Results}

For dose-response experiments, the 137 hippocampal neurons used had resting membrane potentials of $-54.8 \pm 4.5 \mathrm{mV}( \pm 1$ $\mathrm{SD})$ and input resistances of $211 \pm 157 \mathrm{M} \Omega( \pm 1 \mathrm{SD}) . \mathrm{KA}, \mathrm{Q} \Lambda$, and NMDA evoked inward currents in every neuron at resting membrane potential (Figs. $1 A, 2 A, 3 C$ ). An S-shaped semilog dose-response curve was obtained for each agonist (Figs. $1 B$, $2 B, 3 A$ ). At $5 \mu \mathrm{M}$, CNQX reversibly reduced inward currents produced by low concentrations of KA and QA (Figs. 1A, 2A). These reductions were a function of agonist concentration and resulted in a rightward shift of the KA and QA dose-response curves in the presence of CNQX (Figs. $1 B, 2 B$ ), with the same

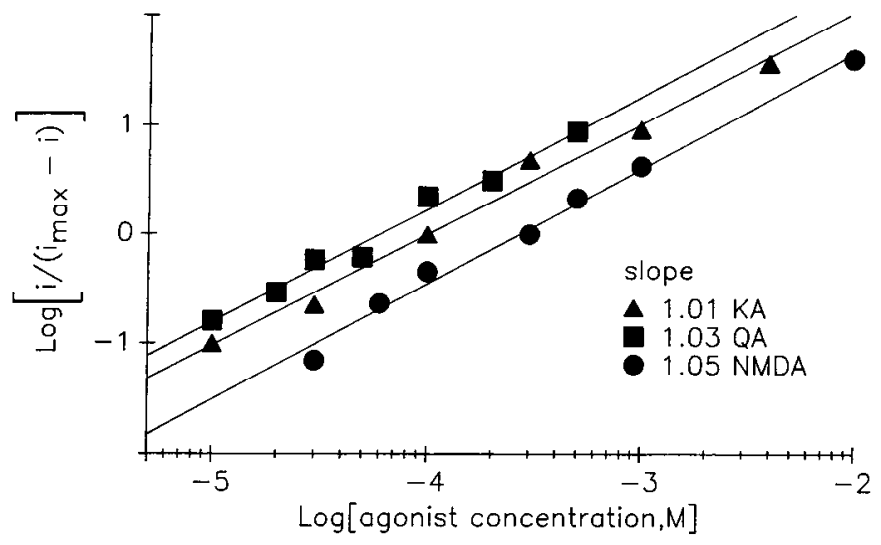

Figure 4. Hill plots for KA, QA, and NMDA. For all 3 agonists Hill coefficients were near unity, indicating that one agonist molecule reacts with one receptor-channel complex to produce a response, see Discussion.

predicted maximal response as the dose-response curves without CNQX. Double-reciprocal plots of response versus agonist concentration, with and without $\mathrm{CNQX}$, were linear for $\mathrm{KA}$ and QA with correlation coefficients $>0.99$ and similar $y$-intercepts. This is consistent with competitive inhibition by CNQX. $K_{d} \mathrm{~s}$ for KA and QA, calculated from equation 2, were 110 and 67 $\mu \mathrm{M}$ (Figs. $1 C, 2 C$ ). The $K_{i}^{\prime}$ 's calculated from equation 4 for CNQX versus $\mathrm{KA}$ and QA, were 2.5 and $3.5 \mu \mathrm{M}$, respectively. The $K_{d} \mathrm{~s}$ calculated from our experimental results are comparable to those from others using similar physiological measurements and in vitro preparations (Table 1).

Low concentrations of CNQX had little effect on NMDA currents, but higher concentrations could diminish NMDA responses (Fig. $3 C$ l). Unlike the situation for KA and QA, extremely high concentrations of NMDA were unable to overcome CNQX antagonism (Fig. 3, $A, C 2$ ). This finding suggested that blockade of NMDA by CNQX might be noncompetitive. The semilog dose-response curves for NMDA alone and with 100 $\mu \mathrm{M}$ CNQX demonstrated different maximal responses using NMDA at concentrations as high as $10 \mathrm{~mm}$. Double-reciprocal plots of the dose-response data yielded lines with similar $x$-intercepts (and therefore $K_{d} s$ ) and different slopes and $y$-intercepts, which is consistent with noncompetitive inhibition by CNQX (Fig. $3 B$ ). The $K_{d}$ for NMDA obtained from Figure $3 B$ was $260 \mu \mathrm{M}$; the $K_{i}$ for CNQX against NMDA was $96 \mu \mathrm{M}$. A plot of $i / i_{\mathrm{CNQX}}$ against concentration of CNQX was linear and independent of NMDA concentration, which is also consistent with noncompetitive antagonism (Fig. $3 D$; equation 8 ). The CNQX $K_{i}$ for NMDA calculated from Figure $3 D$ was $71 \mu \mathrm{M}$. CNQX may interact at the glycine modulatory site of the NMDA receptor as glycine significantly reduced CNQX effects on NMDA responses (Fig. 3, C3, D). It is important to emphasize that all experiments to establish the $K_{i}$ for CNQX against NMDA were obtained in no added magnesium solutions with $5 \mu \mathrm{M}$ glycine, and consequently only apply to these conditions.

The equations used above to obtain binding and inhibitory constants are all derived assuming that only a single agonist molecule binds to the receptor and opens a channel. We tested this assumption by making Hill plots of our data. These were all linear with Hill coefficients of 1.01 for KA, 1.03 for QA, and 1.05 for NMDA (Fig. 4). Thus, the response (inward current) is first order with respect to each agonist. 


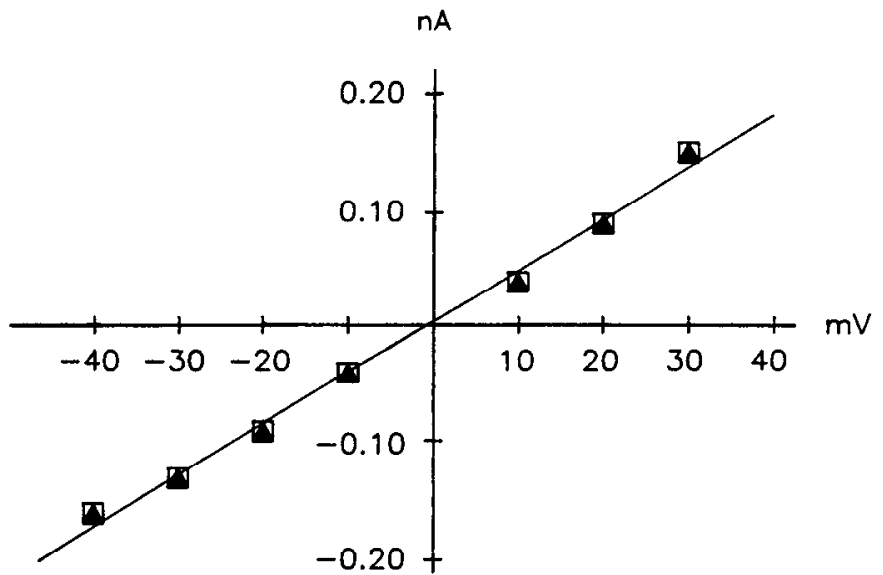

Figure 5. Current-voltage relationship with (open squares) and without (closed triangles) $100 \mu \mathrm{M}$ CNQX. Abscissa, voltage steps from resting membrane potential of $-62 \mathrm{mV}$ (in $\mathrm{mV}$ ); ordinate, current input (in nA). CNQX has no detectable effect on passive membrane characteristics.

Although unlikely, it was also possible that direct effects of CNQX on passive membrane properties might complicate our analysis. Thereforc, we examined the effect of CNQX alone on current-voltage curves of our cultured neurons. The currentvoltage relationship for 4 neurons was linear between -90 and $-30 \mathrm{mV}$ and was unchanged during application of $100 \mu \mathrm{M} C N Q X$ (Fig. 5). No currents were evoked by applications of CNQX at potentials near resting membrane potential. Therefore, the drug has no direct effects on passive neuronal properties. No morphologic changes were observed in neurons exposed to $200 \mu \mathrm{M}$ CNQX for up to $24 \mathrm{hr}$, suggesting that the drug is not toxic to cultured neurons.

Biochemical techniques have already indicated that CNQX is far more potent than any other available non-NMDA antagonist. Therefore, we were interested in comparing it with other antagonists using our physiological assay. We selected the most potent non-NMDA antagonist already characterized, GAMS (Jones et al., 1984), and compared the ability of CNQX and GAMS to decrease KA induced currents. CNQX at a concentration of $10 \mu \mathrm{M}$ reduced the peak inward current in response to a $100 \mathrm{msec}$ application of $100 \mu \mathrm{M} \mathrm{KA}$ to $39 \pm 9 \%$ of the control response $(n=9)$. Using GAMS on the same cells at 10 $\mu \mathrm{M}(n=3)$ and $100 \mu \mathrm{M}(n=3)$ resulted in no detectable KA antagonism (Fig. 6A). At $500 \mu \mathrm{M}$ GAMS diminished the KA current to $82 \pm 9 \%$ of control (Fig. $6 B, n=3$ ). Using the KA $K_{d}$ determined earlier, we calculated that the $K_{i}$ for GAMS was $1.7 \mathrm{~mm}$ against KA. Thus, CNQX $\left(K_{i}=2.5 \mu \mathrm{M}\right)$ was over 500 times more potent than GAMS in blocking KA currents.

Glutamate, acting at non-NMDA receptors probably mediates fast EPSPs in hippocampal cultures (Rothman and Samaie, 1985; Forsythe and Westbrook, 1988). In 7 pairs of monosynaptically connected neurons, CNQX reversibly reduced the amplitude of the EPSPs. CNQX, $10 \mu \mathrm{M}$, reversibly reduced the EPSP amplitude by $71.5 \pm 4.9 \%(n=3)$ (Fig. $7 A)$ and $100 \mu \mathrm{M}$ CNQX produced a $100 \%(n=4)$ reduction in the EPSP amplitude (Fig. 7B).

\section{Discussion}

Honoré and colleagues (Drejer and Honoré, 1988; Honoré et al., 1988) and Collingridge and coworkers (Blake et al., 1988) have reported that $\mathrm{CNQX}$ is a potent and selective antagonist of non-NMDA excitatory amino acid receptors. They have shown that CNQX blocks excitatory amino acid binding, KA- and QAactivated GABA release from cultured neurons (Drejer and Honoré, 1988), depolarization of neurons by iontophoretic application of KA and QA, and extracellular EPSPs in hippocampal slices (Blake et al., 1988). Although these studies are in agreement, none directly demonstrates a reduction in agonist-gated inward currents, which presumably underlies the action of CNQX.

This report is largely consistent with those mentioned above in demonstrating potent, competitive antagonism of $\mathrm{KA}$ and QA by CNQX. However, our results significantly extend the previous observations on the compound by using physiological measurements and conditions to characterize the effects of CNQX on membrane receptors that are definitely coupled to ion channels. We have shown that CNQX potently diminishes inward currents produced by KA and QA and shifts the KA and QA dose-response curves to the right, with no change in the maximal response, compatible with competitive inhibition. The intersecting linear double-reciprocal plots of KA and QA responses in the presence of CNQX are also consistent with competitive inhibition because only the apparent $K_{d}$ is shifted by CNQX (Figs. 1C, 2C).

We were initially surprised that the CNQX inhibition of NMDA appeared to be noncompetitive. We found that high concentrations of NMDA (10 mM) could not overcome CNQX
Figure 6. Comparison of the effects of GAMS and CNQX against KA on 2 neurons. Current traces in response to $100 \mu \mathrm{M} \mathrm{KA}$ for $100 \mathrm{msec}$. $A$ (left to right), Control and with $100 \mu \mathrm{M}$ GAMS and $10 \mu \mathrm{MCNQX} ; B$ (left to right), Control and with $500 \mu \mathrm{M}$ GAMS and $10 \mu \mathrm{M}$ CNQX.
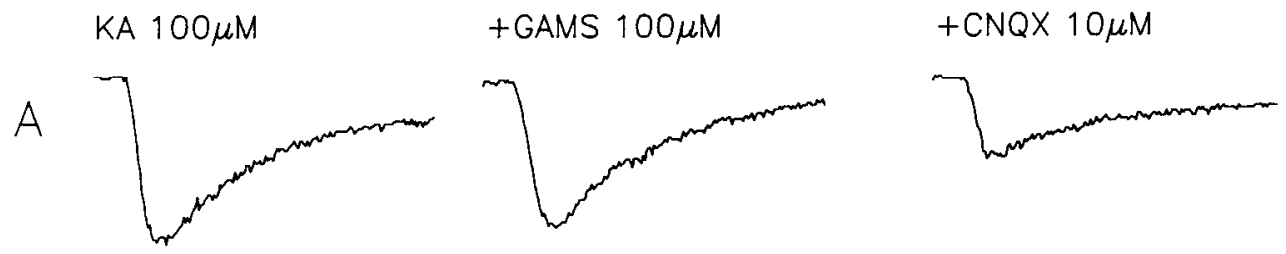

$$
\text { KA } 100 \mu \mathrm{M}
$$
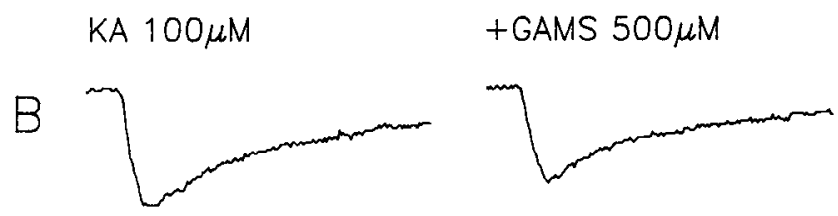

+ CNQX $10 \mu \mathrm{M}$

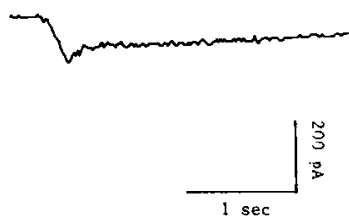


Control:
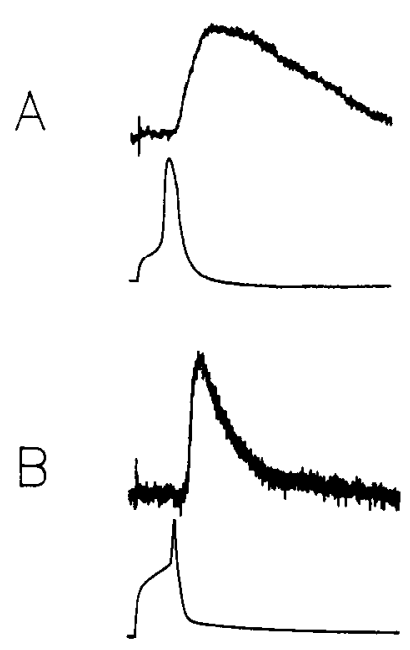

With CNQX:

Recovery:
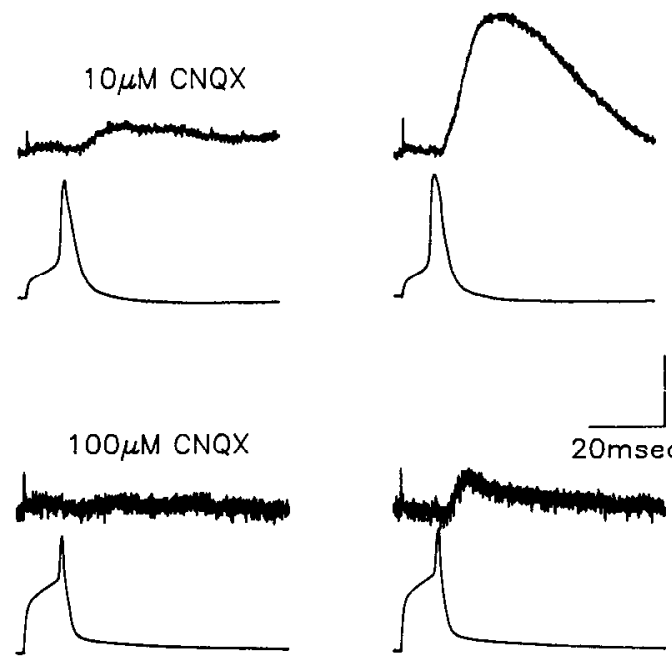

Figure 7. Effect of CNQX on synaptic responses. Top trace in each part of the figure is an EPSP which was produced by directly stimulating a nearby neuron through a patch electrode. Bottom trace shows the presynaptic action potential. $A$ (left to right), an EPSP before, during, and after $10 \mu \mathrm{M} \mathrm{CNQX;} B$ (left to right), An EPSP before, during, and after 100 $\mu \mathrm{M}$ CNQX. There is incomplete recovery following $100 \mu \mathrm{M} \mathrm{CNQX}$. blockade and that the percent reduction of NMDA responses was independent of NMDA concentration. Drejer and Honore (1988) have previously suggested that NMDA blockade by CNQX, and the related compound, FG 9041, is competitive. The most likely explanation for this discrepancy is that Drejer and Honoré's experiments were done with low antagonist concentrations. Under those conditions, noncompetitive antagonism can appear to be competitive (see Barlow, 1980, pp. 160 162). Recently, other investigators have described noncompetitive blockade of NMDA by DNQX (FG 9041) (Birch et al., 1988a).

Our observation that glycine can reduce the block of NMDA by CNQX suggests that both glycine and CNQX interact at the glycine modulatory site of the NMDA receptor (Johnson and Ascher, 1987). Similar findings have recently been reported for the excitatory amino acid antagonists HA-966 and kynurenic acid (Birch et al., 1988b; Fletcher and Lodge, 1988; Pullan and Cler, 1988; Ransom, 1988; Watson et al., 1988). The glycine site may be a common site of action for a variety of agonists and antagonists.

Using our physiological assay, we compared CNQX with the most potent non-NMDA antagonist previously available, GAMS. A complete dose-response curve was not done, but using the results obtained against $100 \mu \mathrm{M} \mathrm{KA}$, GAMS had an estimated $K_{t}$ of $1.7 \mathrm{mM}$. Thus, CNQX $\left(K_{t}=2.5 \mu \mathrm{M}\right)$ is over 500 times more potent when examined directly at the KA receptorchannel complex. This finding is in general agreement with the outcome of binding and release experiments (Honoré et al., 1988).

Our methods of analysis, using the standard equations of biochemical pharmacology, make a number of assumptions that must be satisfied if our calculations are to be meaningful. These include the following:

1. The inward currents we measure must be proportional to the number of occupied receptors.

2. Antagonist and receptor reach binding equilibrium at the time we measure inward current.

3. The agonist-receptor interaction is first order with respect to agonist.

4. Receptors are equally accessible to agonist and antagonist.
5. Concentrations of agonist and antagonist that reach the cell surface are similar to concentrations within the pipette.

It is likely that assumption 1 is largely fulfilled. Drugs were applied at the neuron soma, which was voltage-clamped. The currents generated should be a direct measure of agonist-gated channels and not voltage-gated channels. In order to apply the Henri-Michaelis-Menten equation, a system must be in equilibrium or at steady state (Segel, 1976). At present, there is no data available that would allow us to determine that equilibrium or steady state is actually attained with our brief agonist applications. The fact that our data are well fit by double-reciprocal plots supports either assumption. The Hill coefficients near unity for all agonists suggests that a first-order agonist-receptor interaction is likely.

Chemical differences between compounds may affect their ability to reach sequestered sites. However, in the aqueous extracellular culture medium, it is likely that soluble compounds of similar size (i.e., the excitatory amino acid agonists and antagonists) have equal access to membrane-bound receptors.

Ideally, bath perfusion of the entire culture would insure that all receptors were exposed to a known concentration of CNQX prior to agonist application, but a limited supply of CNQX made this impossible. For our calculations to be valid, the drug concentration in the pipette should approximate the peak local concentration at the neuronal surface. Other investigators (Choi and Fischbach, 1981; Kidokoro et al., 1982) have shown that this is true using similar methods. Two different laboratories using rapid perfusion techniques in vitro derived $K_{d} s$ for $\mathrm{KA}$ and QA similar to ours (Table 1). This is further evidence that pressure application exposes cells to a drug concentration close to that in the pipette.

Evidence has steadily accumulated over the past 5 years that $\mathrm{KA}$ and/or QA receptors are important for fast excitatory transmission in the mammalian CNS (Collingridge et al., 1983). Consistent with this hypothesis, direct intracellular recording in our cultures has shown that CNQX very potently diminishes EPSPs. CNQX, $100 \mu \mathrm{M}$, effectively eliminated excitatory transmission while $10 \mu \mathrm{M}$ decreased EPSPs by over $70 \%$. Similar low concentrations dramatically reduced intracellularly recorded EPSPs (Neuman et al., 1988) and extracellularly recorded EPSPs (Blake 
et al., 1988; Neuman et al., 1988) in hippocampal slices. In comparison, millimolar concentrations of other antagonists have been required to decrease synaptic potentials thought to be mediated by non-NMDA receptors (Rothman and Samaie, 1985; Nelson et al., 1986; Huettner and Baughman, 1988). In addition to being a potent antagonist, CNQX is likely quite specific for $\mathrm{KA}$ and QA receptors. In the presence of $100 \mu \mathrm{M} C N Q X$ in hippocampal cultures, it was not difficult to identify large inhibitory synaptic currents mediated by GABA (K. Holland, personal communication). Interestingly, excitatory synaptic potentials in the isolated spinal cord seem resistant to iontophoretically applied CNQX (Honoré et al., 1988). While this could refiect participation of other types of receptors, it may also be an artifact of iontophoretic administration. Insufficient CNQX released from the iontophoretic pipette or inadequate tissue penetration may explain the results.

The development of CNQX and related non-NMDA antagonists (Honore et al., 1988) is a major advance. For the first time it should be possible to specifically reduce fast synaptic currents and potentials mediated by excitatory amino acids without nonselectively blocking all synaptic transmission. In addition, the 5- to 6-fold reduction of CNQX antagonism of NMDA responses in the presence of glycine suggests that glycine may augment the selectivity of CNQX against non-NMDAmediated responses. At certain synapses it will also be possible to dissect out components mediated by either NMDA or nonNMDA receptors (Blake et al., 1988). Equally appealing is the therapeutic potential of these drugs. Thus far, NMDA antagonists have made it possible to identify a role for NMDA receptors in a variety of pathologic processes in the CNS (Rothman and Olney, 1987). We should be able to learn soon whether nonNMDA receptors participate in these processes. If non-NMDA receptors are also important, use of these or similar agents may allow specific intervention for the benefit of patients with these conditions.

\section{References}

Barlow, R. B. (1980) Quantitative Aspects of Chemical Pharmacology, University Park Press, Baltimore, MD.

Birch, P. J., C. J. Grossman, and A. G. Hayes (1988a) Kynurenate and FG 9041 have both competitive and non-competitive antagonists actions at excitatory amino acid receptors. Eur. J. Pharmacol. 151: 313-315.

Birch, P. J., C. J. Grossman, and A. G. Hayes (1988b) Kynurenic acid antagonizes responses to NMDA via an action at the strychnineinsensitive glycine receptor. Eur. J. Pharmacol. 154: 85-87.

Blake, J. F., M. W. Brown, and G. L. Collingridge (1988) CNQX blocks acidic amino acid induced depolarizations and synaptic components mediated by non-NMDA receptors in rat hippocampal slices. Neurosci. Lett. 89: 182-186.

Choi, D. W., and G. D. Fischbach (1981) GABA conductance of chick spinal cord and dorsal root ganglion neurons in cell culture. J. Neurophysiol. 45: 605-620.

Collingridge, G. L., S. J. Kehl, and H. McLennan (1983) Excitatory amino acids in synaptic transmission in the schaeffer collateral-commissural pathway of the rat hippocampus. J. Physiol. (Lond.) 334: $33-46$.

Cotman, C. W., and L. L. Iverson (1987) Excitatory amino acids in the brain - focus on NMDA receptors. TINS 10: 263 .

Drejer, J., and T. Honoré (1988) New quinoxalinediones show potent antagonism of quisqualate responses in cultured mouse cortical neurons. Neurosci. Lett. 87: 104-108.

Finney, D. J. (1971) Probit Analysis, 3rd ed., Cambridge U. P., London.
Fletcher, E. J., and D. Lodge (1988) Glycine reverses antagonism of N-methyl-D-aspartate(NMDA) by 1-hydroxy-3-aminopyrrolidone-2 (HA-966) but not by D-2-amino-5-phosphonovalerate (D-AP5) on rat cortical slices. Eur. J. Pharmacol. 151: 161-162.

Forsythe, I., and G. L. Westbrook (1988) Slow excitatory post synaptic currents mediated by $\mathrm{N}$-methyl-D-aspartate receptors on cultured mouse neurons. J. Physiol. (Lond.) 334: 33-46.

Francis, A. A., A. W. Jones, and J. C. Watkins (1980) Dipeptide antagonists of amino acid-induced and synaptic excitation in the frog spinal cord. J. Neurochem. 35: 1458-1460.

Hamill, O. P., A. Marty, E. Neher, B. Sakmann, and F. J. Sigworth (1981) Improved patch-clamp techniques for high-resolution current recording from cells and cell-free membrane patches. Pfluegers Arch. 391: $85-100$.

Honoré, T., S. N. Davies, J. Drejer, E. J. Fletcher, P. Jacobsen, D. Lodge, and F. E. Nielsen (1988) Quinoxalinediones: Potent competitive non-NMDA glutamate receptor antagonists. Science 241: 701703.

Huettner, J. E., and R. W. Baughman (1986) Primary culture of identified neurons from the visual cortex of postnatal rats. J. Neurosci 6: 3044-3060.

Hucttncr, J. E., and R. W. Baughman (1988) The pharmacology of synapses formed by identified corticocollicular neurons in primary cultures of rat visual cortex. J. Neurosci. 8: 160-175.

Johnson, J. W., and P. Ascher (1987) Glycine potentiates the NMDA response in cultured mouse brain neurons. Nature 325: 529-531.

Jones, A. W., D. A. S. Smith, and J. C. Watkins (1984) Structureactivity relations of dipeptide antagonists of excitatory amino acids. Neuroscience 13: 573-581.

Kidokoro, J., S. Miyazaki, and S. Ozawa (1982) Acetylcholine induced membrane depolarization and potential fluctuations in the rat adrenal chromaffin cell. J. Physiol. (Lond.) 324: 203-220.

Kiskin, N. I. O. A. Krishtal, and A. Ya. Tsyndrenko (1986) Excitatory amino acid receptors in hippocampal neurons: Kainate fails to desensitize them. Neurosci. Lett. 63: 225-230.

Mayer, M. L., and G. L. Westbrook (1987) The physiology of excitatory amino acids in the vertebrate central nervous system. Prog. Neurobiol. 28: 197-276.

McCarthy, K. D., and J. de Vellis (1980) Preparation of separate astroglial and oligodendroglial cell cultures from rat cerebral tissue. J. Cell Biol. 85: 890-902.

Nelson, P. G., R. Y. K. Pun, and G. L. Westbrook (1986) Synaptic excitation in cultures of mouse spinal cord neurons: Receptor pharmacology and behavior of synaptic currents. J. Physiol. (Lond.) 372: $169-190$

Neuman, R. S., Y. Ben-Ari, M. Gho, and E. Cherubini (1988) Blockade of excitatory synaptic transmission by 6-cyano-7-nitroquinoxaline2,3-dione (CNQX) in the hippocampus in vitro. Neurosci. Lett. 92: 64-68.

Pullan, L. M., and J. A. Cler (1988) Schild plot analysis of the interactions of glycine and kynurenic acid at the N-methyl-D-aspartic acid receptor. Soc. Neurosc. Abstr. 97: 3.

Ransom, R. W. (1988) Kynurenic acid unmasks glycine modulation of NMDA-evoked $\left[{ }^{3} \mathrm{H}\right]$ neurotransmitter release from rat brain slices. Soc. Neurosci. Abstr. 97: 5 .

Robinson, M. B., K. D. Anderson, and J. F. Koester (1984) Kynurenic acid as an antagonist of hippocampal excitatory transmission. Brain Res. 309: 119-126.

Rothman, S. M., and J. W. Olney (1987) Excitotoxicity and the NMDA receptor. TINS 10: 299-302.

Rothman, S. M., and M. Samaie (1985) Physiology of synaptic transmission in cultures of dissociated rat hippocampus. J. Neurophysiol. 54: 701-719.

Segel, I. H. (1976) Biochemical Calculations, Wiley, New York.

Vlachova, V., L. Vyklicky, L. Vyklicky, Jr., and F. Vyskocil (1987) The action of excitatory amino acids on chick spinal cord neurones in culture. J. Physiol. (Lond.) 386: 425-438.

Watson, G. B., W. F. Hood, J. B. Monahan, and T. H. Lanthorn (1988) Kynurenate antagonizes actions of $\mathrm{N}$-methyl-D-aspartate through a glycine-sensitive receptor. Neurosci. Res. Commun. 2: 169-174. 